\title{
The Kirghiz
}

\section{Professor Jules Brocherel}

To cite this article: Professor Jules Brocherel (1902) The Kirghiz, Scottish Geographical Magazine, 18:8, 393-406, DOI: 10.1080/00369220208733374

To link to this article: http://dx.doi.org/10.1080/00369220208733374

册 Published online: 27 Feb 2008.

Submit your article to this journal $2 \pi$

III Article views: 8

Q View related articles $\sqsubset$ 


\section{THE SCOTTISH}

\section{GE OGR A P H I C A L}

\section{MAGAZINE.}

\section{THE KIRGHIZ. \\ By Professor Jules Brocherel. \\ (Translated from the French.) .}

(With Map.)

UNDER the name of Kirghiz is and has been ustally included the whole of the hordes who people the vast extent of steppes and mountains bounded by the Irtish, the Ural Mountains, the Syr-Daria, and the chains of Thian Shan and Tabargatai. It is thus at least that travellers and savants have continued to name these wandering peoples. In the district itself, however, this name is only accepted by the inhabitants of the Celestial Mountains. The nomads of the plain do not in any way know themselves as Kirghiz-they call themselves Kazaks.

The first travellers who came into contact with these barbarians troubled themselves very little about gathering together under the same name all the individuals who, by costume and manners, seemed to them sprung from the same race. They divided them, however, into two great branches-Kirghiz-Kazaks and Kara-Kirghiz. Is it necessary to say that this classification does not rest on any scientific basis? It is picturesque, but not serious.

The Kirghiz have not yet been the object of any careful study. The savants who have observed them were for the most part merely passing through their country, and, further, only took for examination the types whom they met in the towns, and who had, through their town life, been able to modify the original characteristics of the race.

When one wishes to establish parallels between ethnographical subjects of different strata, it is of the first importance to go to the spot and

voL. XVIIr. 
mingle with the tribes which have changed very little, if at all, their inherited characters.

It is to this superficiality of analysis that we owe the confusion of the Kirghiz with the Kazaks. People have confined themselves to bringing ont the appearances of identity, without taking account of the contrasts which arise with them. These two peoples lead the same kind of life, dress in almost the same fashion, and have customs and traditions which vary very little from one to the other. But if we look at the question from the anthropological standpoint, we must admit that there are very pronounced dissimilarities between the two types. The structure of the body, the facial angle, the shape and dimensions of the skull, the exact shade of the complexion, the colour and density of the hair, are hardly at all analogous. It must also be noted that the Kazaks and the Kirghiz each speak a different language, that they mutually hate each other, and that they have never been able to endure being in close proximity.

Furthermore, they have a different point of origin. The Kazaks came from Asia Minor and joined in the migrations of the Nogai Tatars, with whom they have some very evident affinities. It is supposed that the name Kazaks comes to them from a tribe on the banks of the Volga, whose aptitude for horsemanship is said to have struck Alexander the Great, who from that time instituted regiments of cavalry. The name Cossacks is thought to have afterwards become generalised and to. have been applied indiscriminately to all the nomads of the Steppes.

The Kirghiz, on the contrary, seem to have had as cradle the Altai Mountains, whence the Moguls are thought to have dislodged them, driving them upon the plateaus of Tabargatai. By the beginning of the eleventh century they had already made their home in the valleys of the Thian Shan, where they definitely remained.

The earliest mention of the Kirghiz is found in the Chinese annals of the period of the dynasty of 'Thang, which extends from the seventh to the tenth century of our era. As they are depicted by these writers of early times, the Kirghiz were a people with blond hair, black skin, and greenish eyes. Their country was covered with thick snow, and the rivers used to freeze down to half their depth. Their king bore the name of Atze, and dwelt in the Tzing-Chan Mountains. Judging from the examples that they supply, it appears that already at this time the Kirghiz used a dialect allied to the Turkish. Their reddish or blond hair has caused them to be placed, by certain authors, among the Aryan race. This is altogether erroneous, and is based upon an equivocal expression.

The Franciscan monk Giovanni del Pian Carpino (an Italian), and the Dutchman Rubruginus, who traversed Asia in the thirteenth century, recall that they saw, in the course of their journey, some savages flying into the precipices of the mountain. Some years later, Marco Polo, while, crossing the Pamir, lodged in some Kirghiz tents. He cites them as very obliging people, by no means surly. About the same period, the Chinese missionary, Hionen-Tzang, passing through Zungaria, relates 
that he met tribes of Kirghiz pasturing their herds of cattle and taming wild horses.

These witnesses, if they do not say much about the antecedents of the Kirghiz, at least affirm their presence, and agree in describing them in the same light. They themselves are convinced that the inhabitants of the mountain do not form the same people with those of the plain.

The etymology of the word Kirghiz is very difficult to establish. In the Turkish language it signifies those who roam the fields, while in the dialect of the nomads the word indicates forty daughters-Kar-Keuz. These are purely accidental synonyms which in no way clear up the true meaning of the word. Phonetically this word reveals mingled sounds of Chinese and Turkish, from which it might be inferred that it is a transfer into Turkish of a Chinese word. This hypothesis is the most probable one. The word is pronounced differently on the two slopes of the Celestial Mountains-on the north side the people say Keurr-Keuz, while towards Kachgaria they bring out the Chinese nasal, Kir-ghiz.

Further, by following the stages through which the name of this people has passed, we can find, connecting the two appellations, a very clear phonetic link, which strongly supports our supposition. It was the Chinese who first gave a name to the Kirghiz. In early times they were known by the name of Kien-Kouen, then by that of $H a-K a$ and of Ka-Kia-tzi. When they had their abode on the Celestial Mountains they. were called $K i$-zi-li-tze, later, after an interval of some centuries, Kir-Ki-tze, and finally they received the name Kirghiz.

The Kirghiz have been classed among the representatives of the Turkish race, perhaps because of the religion which they affect to profess. Their physique is essentially of Mongolian origin.

The Kirghiz is generally well-built and of a strong constitution. $\mathrm{He}$ is slightly above the middle height, and his limbs are well proportioned. His forehead is low and projecting, his cheek-bones prominent, his chin pointed, his nose flat and squat at the base. His eyes are black and small, raised at the corners, and so recalling those of the Chinese. His neck is slender, the attachments of the muscles fine, and the feet and hands relatively small. The hair is almost always black and smooth. The beard and moustache are very scanty, and fall after the Mongolian fashion. Sometimes blond types are met with, having grey or blue eyes, but these are isolated cases.

It is rare to find among the Kirghiz individuals who are deformed or stunted. This natural selection and the robust constitution which they all possess, proceed from the fact that the rigorous climate and the brutal life that they lead, in the open air, on the mountains, strengthen them remarkably, at the same time eliminating sickly children in the cradle.

A physical peculiarity which is often verified among the Kirghiz, is to have the ears pressed down and the posterior part of the skull forming a flat surface. But these are purely accidental defects. The first is due to their head-dress, which, pressing down heavily upon the head, tends to thrust out the superior lobes of the acoustic organ: The flattened 
form of the skull arises from the custom which the mothers have of swaddling their newly-born infants in stiff skins, which, not yielding to the weight of the head, squeeze it out of shape.

The men have generally a pleasing appearance. The women, on the contrary, are rather ugly than otherwise, and strongly betray characters of the Calmuck type. The nose is flatter, the eyes closer together, and the face more triangular than those of the men. As they do not veil themselves, and work constantly out of doors, their skin is as a result sunburnt and of a very disagreeable brick-red. While they are still

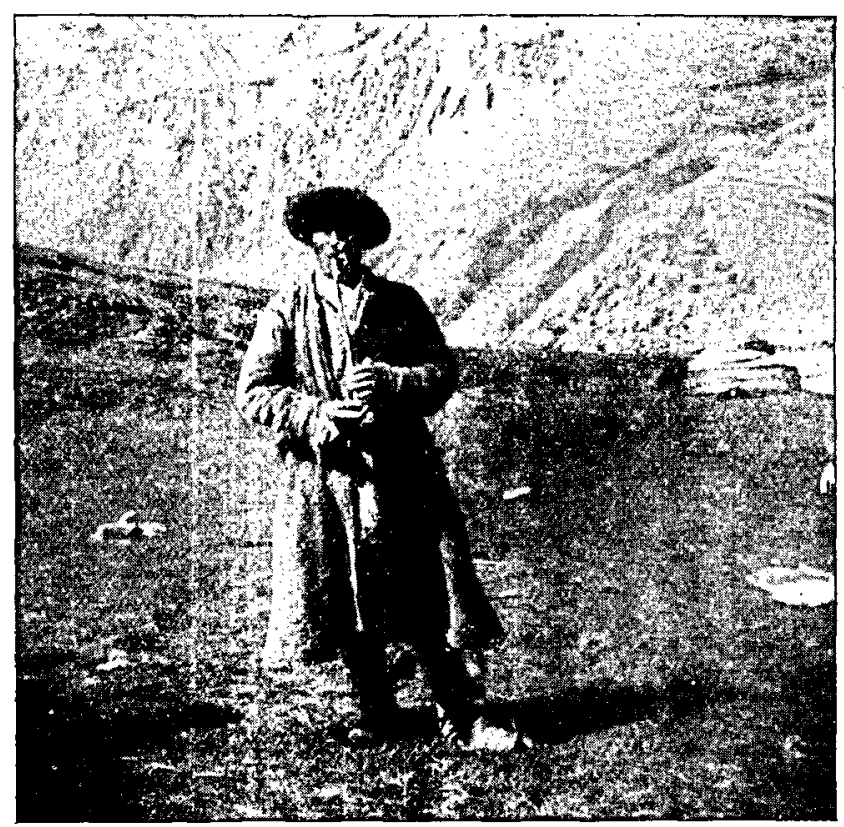

FIG. 1.-Young Kirghiz playing the flageolet.

young, and are left unemployed, they appear, if not prepossessing, at least capable of arousing sympathy.

Before she marries it is usual for the young girl to remain quiescent in the paternal yurt (tent) for a longer or shorter time, in order to fatten herself up ready for the day when she will belong to a man. The Kirghiz, like the Arab, only sees beauty in a woman if she is of rounded form and excessive stoutness. But after two or three years the muscles relax and the flesh sinks down, furrowing the body with a network of wrinkles, and giving the woman a hideous and repulsive appearance.

The Kirghiz are not exactly of excessive cleanliness, but neither can one fail to recognise in them a certain respect for their person. Although they live in constant promiscuity with their animals, and plunge about in the mire, they are often decently and becomingly dressed. They 
always wash before and after a meal, and during hot weather they often bathe in the stream which traverses their village.

The costume of the Kirghiz is very elementary. Above a shirt of printed cotton, with sleeves disproportionately long, and wide trousers likewise of cloth, gathered in to the waist by a string, the Kirghiz, man or woman, puts on a sort of coat made of padded linen, which is fastened on the chest by buttons, or simply held together over the stomach by a scarf tied round the waist. The sleeves of the coat are very short, not even coming to the elbow, so that the shirt falls over the hand and has to be thrown back every moment by a quick movement of the wrist. The Kirghiz have performed this gesture for centuries.

Add to this a kind of boot coming to the knee, with a heel at least ten centimetres high, and a cap of leather or cloth hiding the baldness of the carefully shaven skull, and you have before you the whole equipment of a Kirghiz.

This rudimentary costume constitutes the indoor toilet, or, if you prefer, that which is generally worn in the aul (encampment) in summer. In cold weather and on journeys, however, the Kirghiz protects himself against the inclemency of the seasons by breeches of skin and an ample chapan, a sort of overcoat which covers his whole person. According to the temperature, he wears one, two, or even more, if necessary. He then covers his head with a round hat of white felt, of which the flaps, edged with a wide black plait, droop in front and are caught up at the back. This piece of headgear is a Chinese reminiscence, and, as it is not always easy to get it, it is replaced by a cap of coarse felt, lined with lamb's wool having the hairs inwards, the edge, folded outwards, forming a sort of cushion around the head. This head-dress is not at all ungraceful, and admirably completes the costume. It has especially this advantage, very valuable on the mountains, that it admits of being pulled down over the ears and of being worn with the hair outwards in case of rain.

The women dress exactly like the men, only the details varying. Thus the boots are more elegant, embroidered with silk, ornamented with crimped leather, brightly coloured, and with copper points on the sole and heel. The trousers are wider and longer, and the chapan is of a richer and more conspicuous stuff, sometimes of silk from Boukhara or Kachgar. When they work, they wear a heavy, padded apron, in order to protect their knees against the roughness of the soil.

What especially distinguishes the Kirghiz women is the white cap which covers their heads, giving them a monkish look. Imagine a cylinder, thirty centimetres high, made of a band of starched linen, rolled round the head and with the two ends floating down the back. The hair is carefully drawn up and imprisoned in this box, which serves besides as a pocket in which to place temporarily the trifling objects which a woman needs each moment. Thus, as you see, it is very useful. From the back hangs a chain, carrying attached to it, at its lower extremity, a bunch of keys and of copper plates, which falls to the heels in such a way that at the slightest movement you hear a clinking of iron like that which a convict makes when he walks. 
On great occasions the Kirghiz women adorn themselves with silver jewellery, deck themselves with gewgaws and tinsel, and/smear their skin with mutton fat.

The turban, the "eletchik," is the badge of married women. Young girls replace it by a cap of fox's fur, with a little plume of eagles' feathers in the form of an aigrette. They divide their hair into several plaits, some of which fall from each side of the temples, while others hang down the back, where they are held together by a square of coloured stuff, edged with hair and ornamented with glass beads and coral.

The young girl in quest of a husband is adorned with jewels and

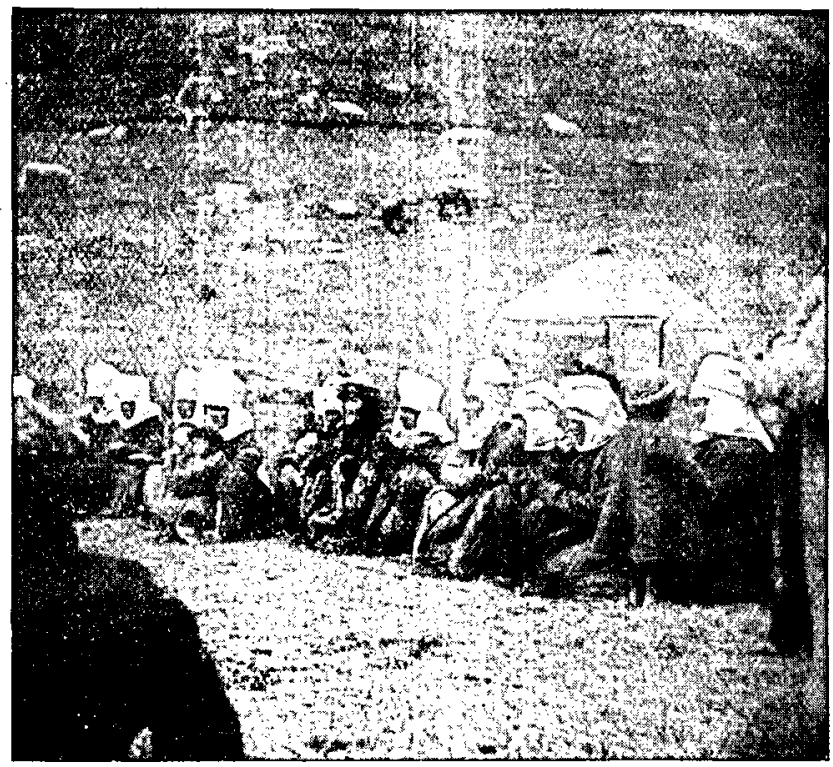

Frg. 2.-Kirghiz women, with characteristic head-dress.

richly dressed. But for this coquetry she has to pay dear later on, when she becomes the slave of a man often brutal, always authoritative.

The Kirghiz yurt is composed of a framework of flexible wood, joined at the intersections by leathern thongs, the whole being fixed in the ground by means of pegs. This wooden structure rises to a height of between two and three metres, being the same in width. The roof is held up by wooden rods, which converge like rays to the middle of the dome, in which there is contrived a circular aperture, which serves at the same time as a chimney and as a window. Upon this slender framework are fitted large pieces of felt, kept attached to it by a system of cords. The whole can be set up or taken to pieces in a few minutes. The tout ensemble forms the load of two camels. 
The interior is very simple. Piles of felt, serving as mattress and coverlet during the night, wooden chests, leather bottles, harness, and other articles of less importance, lie about to some extent everywhere, fastened to the walls or strewn on the ground. Sometimes a curtain drawn across one corner conceals the women's apartment. The entrance is closed by a blind made of felt, which is raised and lowered at will.

In the very middle of the yurt, placed on three vertical stones or on a sort of pedestal made of iron, is enthroned a large cast-iron pot-the kazan-in which the nomads do their primitive cooking.

The Kirghiz, being scarcely acquainted with matches, kindle their fire by rubbing on a stone. Each of them is furnished with a tinderbox, which never leaves him, any more than does a knife with fixed blade which serves the most diverse uses-for killing animals, shaving his own. skull, cutting wood, etc.; it is, in a word, the sole cutting instrument which he possesses.

Well-to-do families have bowls made of earthenware or of wood that has come from Russia. These vessels are carefully wrapped up in rags and shut up in boxes kept for the purpose, which are only opened on great occasions.

The Kirghiz live almost exclusively on koumiss, a heady drink made of fermented mare's milk, which, drunk to a certain amount, produces giddiness and even intoxication. Gulping down this liquid requires a strong digestion, for it contains a quantity of dirt and gives off such a smell that the mere sight of it arouses nausea.

But the nomads are passionately fond of it, and in order to have some after a long abstinence are capable of committing acts of madness. The bottle of koumiss is at the disposal of passers-by, and is never refused to travellers. Also, when he sets out on a march the Kirghiz does not trouble to provision himself with enough for the journey. He always counts on the auls that lie scattered along the road.

Apart from the koumiss, his favourite drink, which he uses every moment, and without which he could scarcely live, the Kirghiz only takes one meal a day, and even that not every day. Assembled in the yurt, ten, fifteen, twenty persons crouch round the kazan, which is capable of holding an entire sheep. Each of them pulls out the dagger which hangs in a sheath at his girdle, lays hold of a bone, and gnaws it so long as any trace of nourishment remains on it. Afterwards every one takes in turn a draught of the broth until it is exhausted, washing down the whole with copious drinks of koumiss. After having fortified himself in this manner, the Kirghiz willingly lets himself fall into the state of somnolence inevitable to laborious digestion.

However, on gala occasions the ordinary fare of sheep, goat, or horseflesh is replaced by daintier and choicer dishes. The dish which is the most in honour and which Europeans can swallow without too great repugnance, is prepared by stringing on a stick alternate pieces of meat and balls of fat, and then cooking them slowly on hot ashes. This is what is called Chizliks. Another dish-the kainagam-is prepared by grating and then kneading together in broth flavoured with aromatic herbs, pieces of cooked meat. The whole then forms a blackish and 
very thick paste, which is swallowed I do not quite know how. Merely to see it manipulated is enough to take away one's appetite.

Some Kirghiz also use tea and bread. However, the latter is made on the spot and of barley meal, rolled into balls and roasted with mutton fat.

The Kirghiz people roam over a district exclusively mountainous, the area of which may be estimated at about 4500 square kilometres. The extent of their domain is comprised within $74^{\circ}$ and $81^{\circ}$ East Longitude, and $40^{\circ}$ and $43^{\circ}$ North Latitude. The Kirghiz are penned up in the high valleys of the Central Thian Shan, almost all on Russian territory, and they are under the jurisdiction of the governor of Pijevalsk, a district of the Province of Semiretchensk.

On the north they have as boundaries the Alexander and Ala-taonTranslian Mountains; on the east they hardly go-beyond the chain of the Khan-Tengri ; on the south the valley of the Kok-chaal-Darya ; and on the west the Ferghana. They are enclosed by four distinct racesthe Kazaks, the Kalmucks, the Kachgarians, and the Tadjiks.

They are divided into two great sections, that of the left and that of the right. The first, called the Sol, comprises the upper basins of the Narin; the Syr, the Oxus, and the Kok-chaal-Darya. It numbers four tribes-Koutchi, Saron, Mendouz, and Kitais. Under this last name are designated the inhabitants of Chinese territory. The second branch, called the $O_{n}$, resides in the basin of the lake Sassik-Koul and in the valleys adjoining the group of the Khan Tengri. It numbers seven tribes-Bougou, Sary-Baghichtck, Sou-Baghichtck, Soulton, Zehierik, Sagass, and Bassiutz.*

The Russian Government has classified them differently, calling them by the name of the valley in which they habitually encamp. Thus Tounghensky designates the individuals who frequent the valley of Tounghent-ak-son, and so on with the rest.

It goes without saying that the Russians do not know the exact number of their Kirghiz subjects. Most of them at present still avoid payment of the tax; although so moderate, of a rouble and a half per yurt. The Kirghiz are only nominally under the rule of the Czar; as far as tribute goes, they have remained as they were before the occupation of Turkestan. Their mountainous and often inaccessible country lends itself admirably to keeping away all desire after official control.

It is impossible to make even an approximate estimate of the number of individuals included in the Kirghiz people. Some speak of 300,000 or 400,000 , but they are certainly more numerous than that. However, even the chiefs of a village do not know exactly the number of the members of the aul, though they know that of their herds of cattle.

The Kirghiz have no very definite ranks of society. They owe obedience to no one, save of course to the Russian Government. However, the latter has nominated responsible chiefs in each tribe, or rather it recognises the authority of the persons whom the auls elect as civil and judicial representatives of Russia. According to the importance of the tribe these are called Kallehi, Chirtai, or, Boloch. These chiefs 


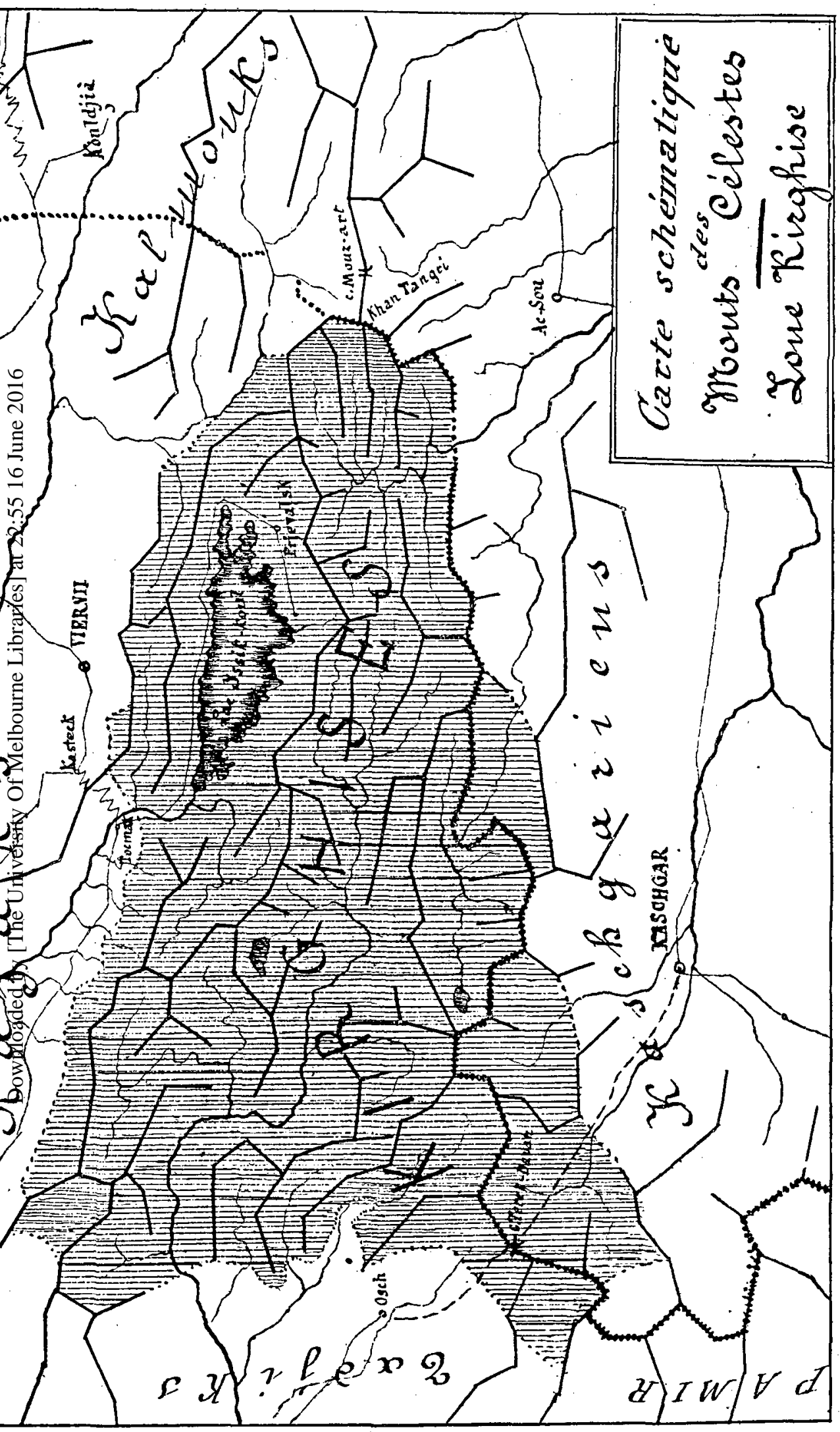


only enjoy prestige if they are rich. It is they who decide the differences which arise between tribes and individuals, and who punish those guilty of a crime or misdemeanour. But it must be confessed that they hardly ever make use of this prerogative; rather than incur unpopularity with their subjects, they prefer to leave matters to arrange themselves.

The Kirghiz have always been, and will be for a long time to come, a pastoral people. Some have wished to accustom them to agriculture, and an attempt in this direction has been made near Pijivalsk. But they scarcely felt any vocation for it, and the fields of oats were quickly deserted for the lofty solitudes of the Thian Shan. Nevertheless, agriculture might be made to succeed wonderfully in these regions, for the soil is fertile and there is never any lack of water. It would bring wealth to the country and easy circumstances to the inhabitants.

For the Kirghiz, a simple people, devoid of all ambition, happiness consists solely in eating a great deal, in sleeping still more, and in disposing of a perpetual far niente. Men, women, and horses, it is all that they ask for. Their lives flow on peacefully between their families and their flocks. They avoid all that might disturb their tranquillity.

They shun a sedentary life, and could not shelter under any other roof than the dome of a yurt. When a Kirghiz has to go to a town to conclude a bargain or make a purchase, he never passes the night there. He hasteris to rejoin the first encampment of nomads, where he anticipates hospitality.

If the ancient world placed the Tartar in these mysterious regions, and thought it recognised in these savages the figure of a Centaur, half man and half horse, it must be agreed that the Kirghiz still corresponds to-day to the idea of the Centaur. He must be seen on horseback, agile and erect. He and his horse seem to form only one creature, and he accomplishes thus, without the slightest fatigue, the longest journeys.

The Kirghiz feels in his element only when he is on horseback. His language, not well developed in general, abounds in expressions relating to horses, and he has a particular name for them for each year of their life. He has not, like the Arab, made a cult of his horse-he has not known how to raise and ennoble its nature, but he uses it, and could scarcely live without his steed, who fills a part of his existence.

The Kirghiz horses are far from having the elegance and suppleness of the Kurdish or Persian horses. They are small and thick-set, with enormous belly and shaggy hair, which assumes all sorts of shades. But they are very strong, and can bear the greatest fatigue. Above all, they show exceptional aptitude for travelling in high mountains; they are Alpine climbers beyond compare. They go along precipices, traverse rivers, scale rocks, and cross glaciers with a sureness and ease which cannot but surprise one. They feel the crevasses concealed under the snow, and leap them at a bound; on uncovered ice they pick out the rough places, spreading out their feet so as to have more hold, and they put only the tips of their hoofs in the interstices of the ice, in order the better to hold themselves back.

The Kirghiz breed a large number of horses-or rather, let them 
breed themselves-in order to have a great deal of koumiss. Every season they make a selection of them and go to offer them at the fairs of Kouldja or Kashgar, where they are sold at from 30 to 50 francs each.

To mount them the Kirghiz summarily harnesses them with ropes or leather thongs, and saddles them with a sort of wooden pack-saddle, on which he throws the extra chapan. The Kirghiz horses, although living in the wild state, are very docile, and there is no need to beat them to make them go. They are simply encouraged with the voice.

The Kirghiz, perched on his steed, is very daring, and master of his movements; on the ground, on the contrary, he becomes as heavy as

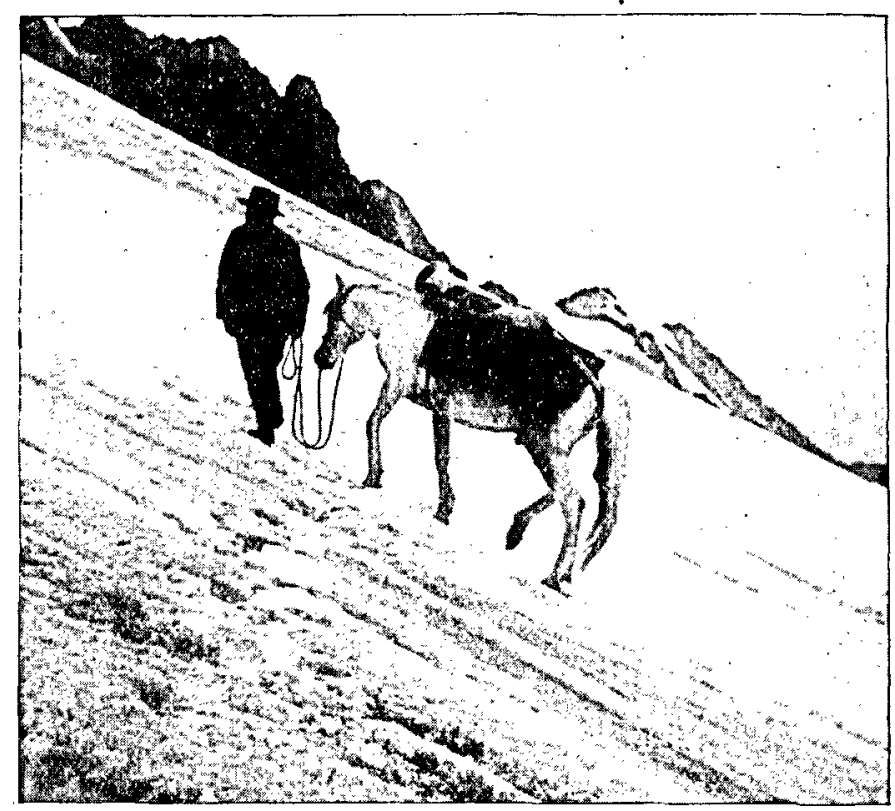

FIa. 3.-Kirghiz horse climbing an ice-slope (Thian Shan).

lead. He detests walking, and, when he can, even avoids going a hundred paces. To get from one yurt to another he keeps a mount permanently in front of his tent. His gait resembles a little the swaying movements of a bear when walking. He cannot stand for more than a few minutes at a time, and one cannot imagine Kirghiz talking in the vertical position. If they have anything to say to each other, they immediately squat down on their heels, one opposite the other, and in this uncomfortable position they are capable of remaining for hours at a stretch.

The horses are only very rarely employed as beasts of burden. For transporting baggage from one tent to another the Kirghiz use camels and oxen. The women ride astride like the men, and the children are already horsemen at the age of six. 
Some travellers have thought the Kirghiz fierce and unmanageable, but they are on the contrary very good-natured. They have not the warlike spirit of their neighbours of the Steppes, who are thievish and indolent. They are above all and before all cowards. They never cherish rancour; after settling a quarrel they become good friends again as before. They are not acquainted with the vendetta, that prompt method of justice which is practised in almost all non-civilised societies.

Side by side with a lively intelligence and a very subtle and ingenious mind, the Kirghiz has a good nature and a naivete which are truly phenomenal. This simplicity of character perhaps proceeds from the kind of life which he leads and from the isolation which he imposes upon himself. He is a fatalist in the highest degree. Everything is for him a good or evil omen; the fall of a filament on a white stone, the red or yellow light of the flame, the colour or form of a cloud, the meeting with such-and-such an animal or the sight of such-and-such a flowerall that has a meaning for him, and on these mere nothings he often bases the acts of his life.

For exorcising evil spirits he has recourse to all sorts of expedients, and his childishness is without limits. Thus a stone that is slightly strange, the presence of a bush in the crack of a rock, the phosphorescence of an animal, or the unusual warmth of a hot spring, assume for him the proportions of a miracle, and he only approaches these objects after waving his arms and making repeated genuflexions.

The Kirghiz call themselves Sunmite Mohammedans, but are not really so. They perform neither the ablutions nor the prayers prescribed by the Koran; they have neither mosques nor mullahs, and have no acquaintance with pilgrimages to the tomb of the prophet. In fact, they do not profess any very distinct belief; they rather imitate a little all the Shamanist sects which formerly flourished in North Asia.

But there is one precept of the Koran which the Kirghiz follow to the letter, namely that which counsels plurality of wives. As far as the number of his herds renders it possible, the Kirghiz will marry one, two, or three wives, and even more if he can.

The number of his wives is in proportion to the quantity of cattle that he possesses, for the Kirghiz buys the former at this marketable value. Sometimes the price is even raised, if it is the young daughter of a chief or of an important personage. She is then worth as much as twenty or thirty thousand francs.

The men marry very late, for the sons have to wait till their father has ceased to form new marriages, so that they may dispose of the herds.

The women, marriageable from the age of ten, marry early, but after two or three years of marriage they are old and worn out. They have few children.

The education of the children is quite Pantagruelian. They prowl about naked like animals, crying hunger on all occasions. Gorged on a milk-diet, they become as dumpy as little barrels. No one looks after them; they grow like the animals, getting thin in winter and fat in summer, just like the mares, and, like the latter, delighting in the high pastures of the mountain. 
The Kirghiz live in, and lead their flocks into, definite places. Each tribe and each aul encamps always in the same valleys and on the same spots. On the approach of cold weather they join their winter camp, and on the return of hot weather they reoccupy their summer encampments. They set up their yurt on the same spot, and they place their kazan on the same stones, which they easily recognise, the flame having calcined them.

The children succeed their parents, who have bequeathed to them rights over the pastures, aptitudes for eating a great deal and sleeping still more, and, with that, very fixed customs, which bring it about that their actions, whether it is a question of the construction of a tent or of the care to be given to the cattle, are often determined by superstitions having the force of law, because they have been consecrated by the ages and handed down through a long succession of ancestors.

The Kirghiz do not feel any very strong affections. They are not capable of a deep emotion; everything is indifferent to them, as well the most immediate danger as the happiest event. They never boast, and in presence of danger they do not lose courage.

Their brain, from not being able to manifest and reflect itself, becomes atrophied in a perpetual inaction. Being acquainted with nothing beyond his family, his yurt, and his cattle, the Kirghiz willingly ascribes an improbable meaning to all that goes beyond the restricted framework of his comprehension.

Having no immediate contact with civilised peoples, they hardly see the utility of knowing how to scribble on or decipher a piece of paper. They are all illiterate.

The Kirghiz language is very composite, but also very poor and rudimentary. Of Turkish origin, it has borrowed a little from all the mediums through which the people have passed.

The word son serves to designate water in general, springs and rivers; mouz, ice and snow; tchion, all that is large in volume and quantity; Darë generalises and includes all the therapeutics of the nomads. The meaning of a word is modified by laying more or less stress on the vowels; thus taon, height, becomes talaon for a great mountain, and so on.

The Kirghiz have never had any literature. The stories that they tell each other on the long winter evenings, and the laments which they pour forth in moments of recreation, have been passed on from generation to generation and from one to another. Sometimes they accompany their songs with a lute, or else they play a flageolet, made from the. branch of a tree.

Since they are devoid of artistic sense, the objects which surround them are very rustic, and hardly ever embellished with those naive ornamentations with which childish peoples delight in adorning their instruments and their habitations.

The Kirghiz tombs certainly sometimes betray an original and personal style. They are composed, according to the importance of the deceased, of piles of stones heaped up in pyramids, of trunks of trees laid across each other, of cones of potter's earth arranged in steps, or of high 
walls pierced with holes so as to form designs, or of canopies supporting a pole, on the edge of which are placed different emblems, as horses' tails, animals' skulls, and glass beads.

The Kirghiz are made up of antithesis and enigmas. Side by side with ancestral defects peculiar to the race, they display dispositions which only require to be cultivated and developed. As long as their mountains remain uncultivated and ramparts of granite separate them from the rest of the world, these nomads will remain as they are. For them to walk in the way of progress and to accept another life, another race more powerful than their own must draw them into it.

That will not happen very soon-Central Asia is too vast and too scantily peopled. Russia, which owns it, has not sufficient hands to cultivate it. The former fertility of this peculiarly favoured region, which has however been laid waste by wars, can only return with an influx of new vigour.

Perhaps the construction of a Central Asiatic railway uniting the Trans-Caspian with the Trans-Siberian, and the carrying into effect of the grandiose project of Richthofen, passing through Zungaria and the plains of Hoang-Ho as far as to Chang-Hai-perhaps, I say, two works like these will one day put an end to the decrepitude of this land, and rejuvenate these peoples.

\section{A NOTE UPON THE METHODS OF BOTANICAL GEOGRAPHY.}

By Marcel Hardy, Botanical Institute, Montpellier.

WHEN we seek to put in relief, with the aid of graphics, the ecological conditions of vegetation, we have to choose between two methods, very different yet with numerous points of contact between them, which may give in certain cases identical results. The floristic method, adopted by H. C. Watson in England, and followed, after him, by the majority of English botanists, has been brilliantly expounded and discussed in France by Alphonse de Candolle. The geographic or ecological method has been defined by Warming, and put in practice by some botanists, among whom we shall cite only M. Flahault in France and Robert Smith in Scotland.

- Though these two methods of considering vegetation have been frequently discussed, it may not be useless to consider them once more in order to show their close relationship and to arrive at a definitive choice in view of the work which has still to be undertaken.

Watson thus defined his method $(8)^{1}$ : "To group methodically all the facts which show the general distribution and the particular habitats of plants distinctly indigenous or fully naturalised; then to determine the physical causes which influence their actual distribution." In applying

1 Figures refer to bibliography at end of article. 